\title{
Promoting child-friendly school model through school committee as parents' participation
}

\author{
Somariah Fitriani, Istaryatiningtias \\ Magister of Educational Administration Department, University of Muhammadiyah Prof. DR HAMKA, Indonesia
}

\begin{tabular}{l} 
Article Info \\
\hline Article history: \\
Received Mar 26, 2020 \\
Revised Sep 20, 2020 \\
Accepted Oct 29, 2020 \\
\hline
\end{tabular}

\section{Keywords:}

Child-friendly school model

Parent involvement

Parent participation

School climate

School committee

\begin{abstract}
The study intended to elaborate on the role of the school committee in addressing and promoting the implementation of the child-friendly school model to create a positive school climate and atmosphere. This qualitative approach research adopted a comparative case study since two primary schools become a unit of research analysis. Two primary schools, a public and private primary school in which both of them are located in Jakarta as a study site. The researchers obtained the data through observation, interviews, and document analysis. The research has revealed that the school committees, both in public and private schools, bring a vital contribution to help the schools in terms of supporting and controlling the implementation of the child-friendly school model with several different perspectives. The participation of the school committee is highly needed in monitoring the activity of the learning process toward the quality of school life and in bridging the communication between schools and students' parents, particularly in promoting the model of child-friendly school.
\end{abstract}

This is an open access article under the CC BY-SA license.

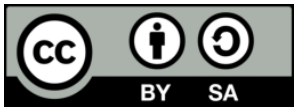

\section{Corresponding Author:}

Somariah Fitriani,

Magister of Educational Administration Department,

University of Muhammadiyah Prof. DR HAMKA,

Jalan Warung Buncit Raya No 17 Pancoran Jakarta Selatan 12790, Indonesia.

Email: somariah@uhamka.ac.id

\section{INTRODUCTION}

The definition of the Child-Friendly School (CFS) is constructed on the Education for All Declaration (EFA) based on the philosophy of children's rights, which views children's development as central to education's position [1]. The notion emphasizes the application of the Child Rights concept, which three main principles of child-centeredness, democratic participation, and inclusiveness are at the heart of the Child-Friendly School definition [2]. The CFS model aims at thoroughly engaging and promoting all stakeholders to strengthen the right of children to good education, including parents, families, teachers, heads of school, educational administrators and civil society groups, local and national governments, and their external partners [3]. In other words, by having a partnership with all parties, particularly parents as the current research focus, the model of child-friendly schools can be fully implemented and achieved to address the needs of children as learners.

The involvement of parents plays a valuable role in the cognitive, affective, and psychomotor development of the child's growth and learning process. Research shows that parental involvement has a high magnitude in children's educational processes and outcomes [4]. The children also have to feel secure, comfortable, and enjoyable at school without being discriminated against or bullied due to differences in ethnicity, skin color, religion, gender, and socioeconomic background. Data from UNICEF shows that approximately 300 million children around the world become subject to exploitation, violence, and abuse [5]. 
Thus, the school needs to provide a friendly learning environment to develop their cognitive, affective, and psychomotor state. Batelaan emphasized a democratic and safe school atmosphere to make students more at ease to interact with each other by promoting intercultural education. The students learn how to value through experience with interactions within the classroom and school in cultural education [6]. To provide such an atmosphere, Polat and Barka pointed out that school administrators and teachers as classroom managers have a primary role. They are required to have positive attitudes towards intercultural education to act their role successfully [7]. The teacher is also a contributing factor in creating quality learning and education, particularly in disseminating the idea of respect and character building, which impacts students' behavior and attitude [8].

Not only does the school need to provide such an environment, but also parents' contribution has profound impacts. The involvement of parents in any kind of form is empirically proven in quality education. For instance, the report found clear and steadily increasing evidence that families can enhance the academic performance of children in school and have significant impacts on attendance and behavior conduct [4]. High levels of parenting support and a pleasant school climate for students, even in disadvantaged families, encourage autonomy and self-esteem [3] since the majority of behavior issues are derived from behavior patterns established during the children's early childhood [9]. In addition, the report revealed that children between 5 and 7 years old undergo a developmental transformation that leads to significant changes in personal responsibility, independence, and social roles in a healthy social environment [10]. Curwin also pointed out that the critical years between the ages of 9 and 15 are an ideal and fundamental time to teach such students to accept responsibility for the consequences of their behavior. In those ages, the students are taught to recognize that mistakes can become chances for learning and to assist them in learning how to formulate and live with the classroom and the rules of community that promote responsibility, respect, and self-discipline [11].

Consequently, teaching them to be responsible, discipline, and respectful to their peers in early intervention will shape their behavior and attitudes. However, very few studies have investigated the school committee's role as parents' participation in creating a pleasant school climate and positive atmosphere, particularly in terms of the implementation of a child-friendly school model in primary school. Under these circumstances, the implementation of the child-friendly school model is a necessity to introduce the concept of respect, equality, and rights to primary students.

This study has aimed to fill the gap by obtaining the data from two primary schools, which narrows the focus of research on the school committee. Thus, exploring the role of the school committee in addressing and promoting the concept of child-friendly school model in two different schools which have different backgrounds in terms of socioeconomic aspects is needed. Since very little studies have been conducted to compare between public and private school, this article also attempted to compare the role of school committee as one school is a private primary school, which the students come from an upper-middle-class family and the other one is a public primary school which many of them come from middle-lower class family. As a result, it is imperative to figure out the differences in terms of the role of the school committee in promoting child-friendly school model and quality education.

\section{Child-friendly school model}

The framework of a child-friendly school (CFS) was introduced by UNICEF in 1999 as part of the global need to improve quality education driven by the philosophy of child rights, which regards the position of education as promoting child development [1]. Children's friendly schools (CFS) promote a multidimensional service framework and meet the child's overall needs as a student. CFS models aspire to ensure the full engagement and involvement of all actors in a position to promote the right of children to quality education. Parties such as parents, families, teachers, school heads, education administrators, and civil society organizations, as well as local and national governments and their external partners, are required too. These parties are 'duty bearers.' Their engagement helps schools and educational systems to have the required conditions and resources to achieve the CFS quality standards [2].

In Indonesian's context, the policy of CFS is ruled in the regulation of Minister of State Empowerment of Children and Protection Number 8 of 2014. The Ministry of Women's Empowerment and Child Protection, which works with eleven other parties engaged in the field of education defined CFS as a secure, clean, balanced, loving and developed system that protects children's rights and their safety from violence, discrimination, and other mistreatment and encourages their involvement, precisely in planning, policy, learning, and supervision [12]. In the manual book of CFS published by the Ministry of Women's Empowerment and Child Protection, four principles are stated to develop the CFS model including nondiscrimination, the best interest of the child, life, survival and development, respect for children's views, and proper management which are also aligned with UNICEF's principles, namely child-centeredness, democratic participation and inclusiveness [13]. Furthermore, the CFS model is also one of the indicators to 
develop Child-Friendly Districts/Cities as stipulated in the Regulation of the State Minister for Women's Empowerment and Child Protection Number 12 of 2011.

\section{The interplay of the school committee and parental involvement in education}

The term of the school committee and the school board is interchangeable in many countries. For instance, the United States of America, OECD countries, and the Netherland use the term of school board [14, 15], which has a wide-ranging scope of autonomy relating to the personnel matters, buildings' infrastructure, resources allocation and student assessment [16]. In contrast, in Indonesia, the term of the school committee is more well-known. According to Indonesian's Minister of National Education Decree No. 044/U/2002 on the concept of the school committee and its roles, the school committee is defined as an independent board of body that accommodates community participation in order to improve the quality, equity and efficiency of education management in education units, both in the preschool education level, school education level and non-school education level. Each country has its regulation regarding the role of the school committee. The school committee has three roles, including advisory agency, supporting agency, and controlling agency. As an advisory agency, the school committee determines and implements educational policies in education units. As a supporting agency, it supports the school in the form of financial, thought, and energy aspects in organizing education. The last role is as a controlling agency in the context of transparency and accountability in the administration and output of education in the education unit.

In the words of Rehberg, as school partnership body, the school committee has an important role, which promotes the relationship between schools, families, and communities: 1) policymaking; 2) financial assessment; 3) financial services delivery; 4) linkages to the community: and 5) educational planning and evaluation [17]. Besides, Epstein and Van Voorhis noted that school committees play a significant role in supporting school events, enhancing student performance, and connecting school, family, and community partnerships [18]. Bryan and Henry reported the positive impact on student achievement and discipline when stakeholders (schools, families, and communities) help create relationships [19].

Hooge and Honingh indicated that school boards have a better understanding of the standard of schools when they stick to the leadership position and when school leaders adhere to their management role. Also, the school boards of primary schools have given the contribution to improving the quality of school education [20]. In terms of the members, most school committees are composed of students' parents, whereas in some other countries, it consists of professional members, such as in the Netherland. The number of previous research findings has examined the effect of school boards on several aspects, including academic achievement, and school achievement [21-25]. However, the lack of studies investigated the role of school boards or school committees in terms of the CFS model.

As the school committee typically consists of student parents in many schools in Indonesia, so parent involvement also becomes the focus of the research. Parent involvement refers to the roles of parents in educating their children both at home and at schools [26], and it is framed as a multidimensional framework of three dimensions: home-based, school-based, and parental arrangements [27]. Recent studies have identified parent involvement as a complex and multifaceted concept [28, 29]. Parental involvement can take different forms, including school discussions, homework assistance, or school volunteering, which also tends to have enduring benefits, even in high schools [30]. The role of parents in positive educational results for students has been confirmed by decades of research [31, 32]. All of the above illustrates the various ways in which parents can engage in child education, which in turn can have various effects on children [33]. In terms of reducing bullying, the research revealed that the intervention of a whole-school capacity-building in early and middle childhood might increase the chance and frequency of meaningful contact between parents and children on bullying [34].

\section{School climate}

It is undoubtedly that students can learn better at schools if they feel welcomed both by teachers and peers. A pleasant and conducive learning atmosphere support them to learn better, as well. On the other hand, students will feel indeed severely when they feel threatened, distracted, and unsecured as anxiety obstructs the learning process. Such a learning atmosphere is called school climate, which Pickeral, et al. defined as school life quality and character, include norms, beliefs, and aspirations that help people to feel physically, emotionally, and socially healthy [35]. An increasing body of research shows that school climate influences students' academic achievement and their well being; and personal and social development [36]. The analysis of PISA data disclosed that a positive school climate was connected with student achievement's higher levels [37]. Besides, researchers agree that school climate primarily reflects a subjective sight of the learning atmosphere at the school level [38]. Several other researchers on school climate and its effect on school effectiveness, also noted that a positive school climate affects the overall school's effectiveness [39]. It implies that there is a connection between a positive climate in the school and its effectiveness. 


\section{RESEARCH METHOD}

\subsection{Research design}

The study of the qualitative approach adopted a comparative case study method since the objective of the study was to gain insight into the role of the school committee in promoting and addressing the concept of the Child-Friendly school model in two distinguished schools. The case study is employed when a small group of a school becomes a unit of analysis [40, 41]. Gall, et al. emphasized the four characteristics of a case study, including a profound analysis of one or more of the real-life phenomena instances and perspectives of the participants in the phenomena [42]. A comparative case study is a research method for formulating or testing generalizations spanning across multiple cases. From the intersection of comparative and case studies, the character of comparative case studies can be explored [43]. This method potentially leads to more exceptional interpretation and theorization of a variety of events [44]. Such a case study method was used to compare two different schools, in which both of them are located in Jakarta to allow the researcher to have a deeper understanding through more descriptions and details.

\subsection{Participants}

The study employed a technique of purposive sampling to select the schools purposefully, which have implemented the child-friendly school model. After obtaining the campus approval to conduct the research, we visited the school to inform the objectives of the research. The school principals permitted to do the observation and interview with key persons, including the headmaster, vice headmaster, the head of the school committee, teachers, and students. Two schools were selected as study sites for the project research. The public primary school of Ragunan 01 is a school located in South Jakarta, which most of the students are derived from middle-lower family backgrounds, whereas the private catholic primary school of Saint Peter located in North Jakarta, which all students are from the middle-upper family background. The public school has implemented the CFS model since 2015, and the appointed school committee head was selected due to her active participation during the school activity by using voting among student parents, principals, and teachers. The private school has implemented the CFS model before the year 2008, and the head of the school committee was selected by the teacher board consisting of 45 persons. The criteria for selecting the school committee is based on the passion and active discussion with the school.

\subsection{Data collection}

The information was gathered from two primary schools. So, the leading research was primarily conducted in public, and private primary schools as both of them have implemented the CFS model. Data were gathered through observations, interviews, and reviews of the document. The interviews were conducted with the school principal, vice-principal of students' affairs, and curriculum, the head of the school committee, and students' parents by using a purposive sampling technique. The interview with school staff was conducted in a more formal situation at school, while the interviews with the school committee and several students' parents were in a more relaxed condition such as in the canteen and restaurant. In addition to the face-to-face interview, the researcher also used the platform of WhatsApp social media to ask further questions aiming to obtain more accurate data.

\subsection{Data analysis}

The study used a method and source kind of triangulation to check the validity and reliability of the information. The cross-check was conducted to ensure that the data were valid and reliable. The researcher asked nine questions regarding the role of the committee to the headmaster and the head of the school committee. Besides, the interviews were recorded as not to miss any single information from the participants. The researcher employed the content analysis of data on the recording and transcript of interviews and notetaking during the observation. Besides, the method of constant comparative analysis to analyze the data from the interviews was adopted as well. The results of observation and interviews were analyzed by giving code and interpreting it based on literary reviews and previous research findings. The results of nine questions were then written in the form of a table, as seen in Table 1.

\section{RESULTS AND DISCUSSION}

The study focused on the elaboration of school committee participation and involvement in quality education and the implementation of a child-friendly school model. Table 1 shows the results of the questions from two different perspectives about its role. 
Table 1. Results of private and public school

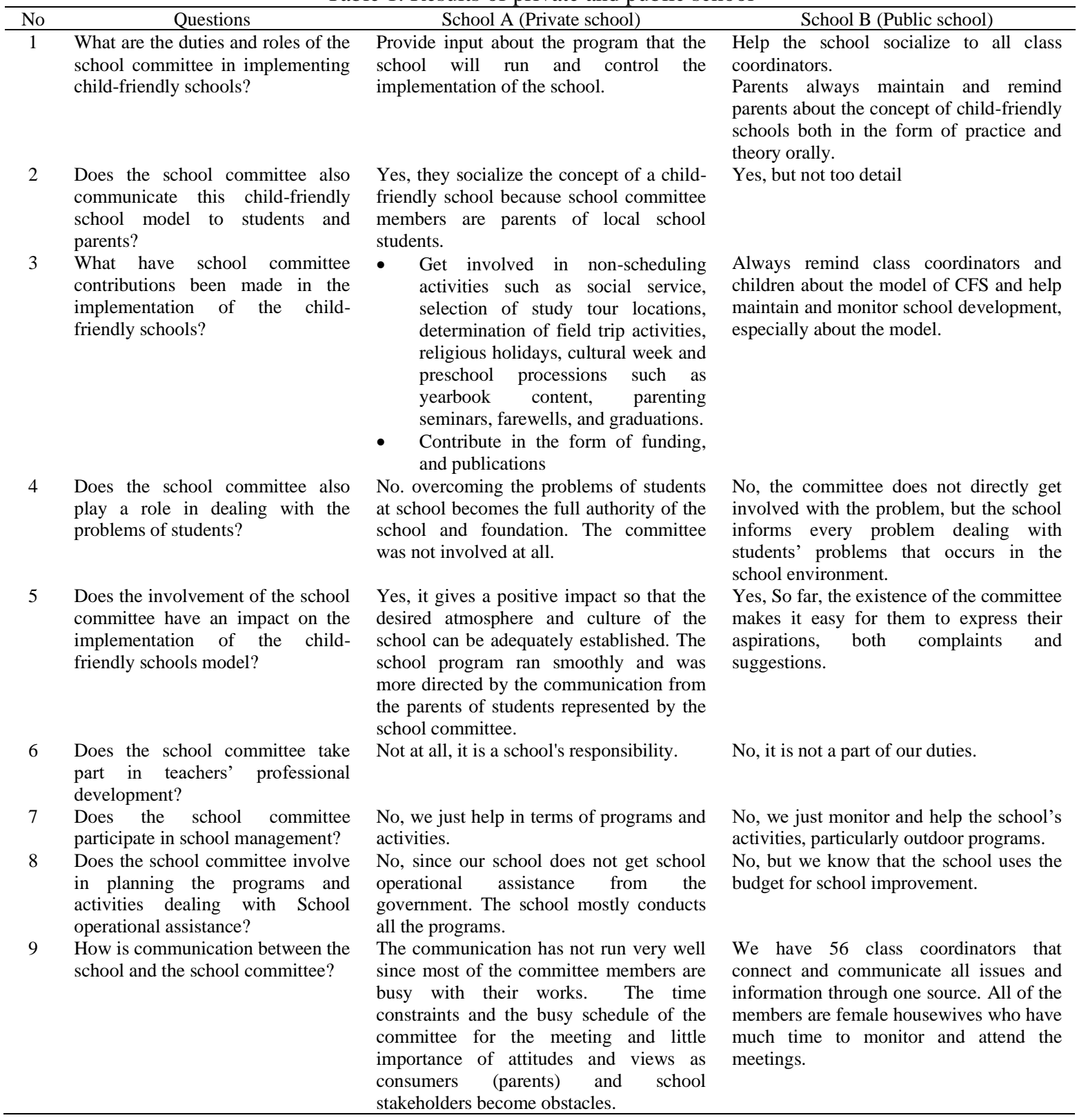

To anticipate behavioral issues such as bullying, discrimination, and such a thing does not occur, the head of the school committee in primary public forms a class coordinator consisting of three parents for each class to control students' behavior, particularly outside of the classroom. Here is the interview with the head of the school committee.

There are 47 class coordinators since there are 22 classes. So, there are three representatives of parents who control and monitor class activity, students' behavior, and outdoor duties. All of them are female housewives who attend school regularly. They take turns to monitor and give reports to the head of the committee if something terrible happens. They are in charge of reporting the problems to the head of the school committee. We used the media of WhatsApp to communicate and share the information (Public school).

Even both schools have many class groups consisting of around 30-32 students in one class, and both of them have a school committee. The involvement of the school committee is somewhat different. To make students feel safe and comfortable, despite creating the school climate by the school staff, the contribution of the school committee in public primary school is more involved than the school committee in 
private school. One of the reasons is that almost all parents, especially mothers, work in the office. Therefore, they rely on the school to create a positive atmosphere. For parents in private schools, which are from the upper-class family, creating a safe, comfortable atmosphere is the school's responsibility. Here is the interview with the vice principal.

The school committee does not regularly attend school since many of them are workers. We just communicate through WhatsApp or make a phone call if an urgent thing happens to students. So, they do not get involved much with our activity. They just help in terms of funding to make sure that our programs run smoothly and successfully (Private school).

One of the different things between private and public school in this current research is the school committee of public school also transfer the knowledge and practical skill to students and monitor their extracurricular activities. Here is the interview with the school committee.

For us, the child-friendly school model is a school, which frees students; they do not feel a burden; they feel comfortable, free to tell story and teachers are not frightening figures. Teachers are like our family, who gives support to each other. That is why we also teach students about how to make compost and waste bank, how to raise fish and feed them regularly, and other things that we know (Public school).

It is concluded that the school committee does not involve strategic planning, financial issues, teachers' professional development, and school management. School committees in both schools just focus on the monitoring of school activities and programs. The school does not involve them, which is different from the regulation of the ministry of education and culture. The Ministry of Education and Culture states that the partnership program through the school committee aims to strengthen the fabric of partnerships between schools, families, and communities in supporting learning environments that can develop the full potential of children; increase the involvement of parents/guardians in supporting the success of children's education at home and school; and increasing community participation in supporting educational programs in schools and the community [45].

According to Law No, 20 of 2003 Article 56 of the Board of Education and School committee, the school committee has a role in improving the quality of educational services, including planning, monitoring, and evaluation of the educational program. Based on the finding of this research, the school committee of public schools has better involvement and participation compared to the school committee of private schools due to the working status and economic background of the parents.

The Ministry of National Education decree no. 044/U/2002 noted three roles of the school committee, namely advisory agency, supporting agency, and controlling agency. Both schools have run the role of supporting agencies with different aspects. The public school committee only provides thought and energy to help the school in holding the activities, while the private school committee provides financial matters in helping the school run the activities and programs. Additionally, since public school is managed and financed by the government, so it is not allowed to get money from the student parents.

On the contrary, private school is managed and financed by the foundation, in which the school asks the school fees and other financial matters to student parents to support the facilities and infrastructure of the school. Here is the interview with the vice-principal of the private school.

The school committee usually discusses the amount of money to facilitate the activities and programs and infrastructure or facilities with parents and the principal.

They usually engage in school events and take part in scheduled parental seminars four times per year, then take part in making the creation day, Independence Day celebration, and graduation day.

Based on the above information, it can be concluded that the school committees in both schools have carried out their roles as supporting and controlling agencies in different aspects. In public school, the school committee only controls the accountability of education outputs and students' activities, whereas the school committee of private school controls and takes part in school programs related to school outputs as well. However, they have not conducted the role of the advisory and controlling agency, as stated in the decree of the Ministry of National Education for several reasons. Both school committees lack the knowledge of their roles, and the schools also do not inform them about their roles. They run their function as a controller in terms of monitoring students' activities and behavior as well. In particular, the school committee 
in public school informs the students about the model of child-friendly schools and the things the students need to know. That is why when the researcher asks about the concept of child-friendly school to several students in break time, they can tell quickly. Here are the interviews with several students when asked about the concept and how they know its concept.

Child-friendly school is a school, which provides a friendly, secure, and comfortable atmosphere for us. We feel free to explore our ideas with teachers. It is a peaceful, clean, friendly, polite school. The school committee, principal, and teacher inform us about childfriendly schools: no abuse, no bullying, no violence, no discrimination (Students).

Based on the above information, schools with the help of the school committee and parent involvement need to provide a friendly, secure, and comfortable atmosphere for students. According to Devine and Cohen, feeling safe in school powerfully promotes student learning and healthy development. In their findings, it is also reported that students feel less safe in large and public schools as well as high poverty schools [46]. Other research has shown that students feel less secure and have a higher chance of verbal abuse in large schools [47]. Fortunately, this situation does not occur in both schools. Studies have also shown that particular interventions involving parents (i.e., mentoring, security monitoring, business partnerships) enhance the conduct of students and that the disciplinary activities of schools [48]. It indicates the need for the school committee and parent participation to get involved in monitoring and controlling the students' behaviors to reduce or anticipate the unwanted occurrence among students.

The earlier studies have shown that higher rates of parent involvement in school events are linked to fewer instances of primary and secondary school violent acts. Parent participation was also a protective factor in schools with a high racial/ethnic minority and located in high poverty [49]. In terms of some form of parental involvement opportunities, the school with increased parental participation and involvement in field activities has decreased abuse rates [50]. The current research has similar findings with the previous research, which also revealed that although the school committee in primary school has not met the 100 percent standard due to several factors, the participation and involvement of the school committee is in a good category [25]. The previous research findings in Indonesia revealed that the role of the school committee had not met the standard, yet due to several reasons [24, 25]. The reasons are because the establishment of school committees is based on the need to meet the requirements in obtaining funding from district/governments and as a requirement in school assessments, instead of the need of stakeholders [51].

Good communication between school and parents or school committees play a significant effect on students. The research has found that when educators actively interact with families and participate in behavior-oriented programs, schools record fewer disciplinary behaviors from year to year [18]. They also emphasized that the standard of school operations, comprising eight main elements: leadership, teamwork, action plannings, execution of plans, funding, collegial support, assessment, and networking, was improved by developing a partnership program among school, family, and community. The relationship systems were retained and strengthened from year to year as these elements were cultivated. Other results demonstrated that the teenagers' perception of family communication and perceived parental encouragement was concerning the possibility of committing delinquent behaviors [52].

A child-friendly school is a family-friendly school [2]. It means that it develops ties with parents and caregivers whose primary responsibility in every step of their growth is to ensure the well being of children. To parents who feel positive about schools and that invest in their lives, the school's principles, policies, and practices will be the best advocate at home, whether they encourage education, promote aggression or endorse collaboration with other people. In that case of stakeholder's involvement, Bryan and Henry have identified a positive effect on student learning success and discipline when stakeholders (schools, families, and community groups) participate in developing relationships [19]. Openness between the school committee and school is also vital to build collaboration and integration to make a school child friendly. Rudduck and Flutter also added that supportive family towards children's increased participation at school would make them feel part of the change positively and not threatened by it in ways that might result in a negative backlash against children at home [53]. It is also imperative to introduce the concept of democracy in the implementation of Child-Friendly School to students since one of the main principles is democratic participation [1]. Therefore, Becker, De Wet, and Vollenhoven proposed the theoretical framework, which looks at the ongoing development of an open and democratic society by promoting the human rights' literacy facilitation, rights-based education, and transformative action. They emphasized three things, which support the model of the child-friendly school [54].

By facilitation of human right's literacy, right based education and transformative action, all parties in school environment are encouraged to understand and promote human rights. However, Slater pointed out the challenge for the school is that educating all pupils to be responsible members of a democratic 
society [55]. Socioeconomic factors such as today's changing society, poverty, and ethnic background are likely causes of behavioral problems [56,57], which contribute to children's behavior and attitude at school settings [8]. According to De Jong, several best practices to address the issues of students' behaviors are a health promotive culture, the approach of a democratic, empowering and positive classroom management and the partnership of well established internal and external support structure [58], which are relevant to childfriendly school concept. In line with internal and external support structure partnerships, the school committee and parent involvement have a significant contribution to promote the model of child-friendly schools. The current study has aimed to explore the role of the school committee as parental involvement in addressing and promoting the model of child-friendly schools in public and private primary schools, which is aligned with the previous similar research findings.

\section{CONCLUSION}

This study has explored the role of the school committee as a part of community participation in addressing and promoting the concept of the Child-Friendly School model. A child-friendly school model is seen as an instrument to make sure that everyone respects his/her rights and other people's rights to create a positive and conducive school climate and atmosphere, which brings a profound impact to students' development and growth. The study has revealed that the school committee plays a somewhat significant contribution, particularly in helping schools monitor the implementation of the model. Both schools also have carried three roles as the supporting and controlling agency with different functions due to some limitedness of both school committees. The last important point in this article is that if everyone is attentive of his/her rights and other's people rights, understand that everyone is equal regardless of their social status, race, skin color, and religion as well as apply the CFC model to education; the violation, discrimination, and unwanted conditions will never happen at schools.

\section{ACKNOWLEDGMENTS}

The research was supported by Lembaga Penelitian dan Pengembangan (Lemlitbang), Universitas Muhammadiyah Prof. DR. HAMKA.

\section{REFERENCES}

[1] E. Godfrey, et al., "Cross-national measurement of school learning environments: Creating indicators for evaluating UNICEF's Child-Friendly Schools Initiative," Child. Youth Serv. Rev., vol. 34, no. 3, pp. 546-557, 2012.

[2] UNICEF, Manual: Child friendly schools. New York: UNICEF, 2009.

[3] UNICEF, The Child Friendly School manual. New York: UNICEF Division of Communication, 2009.

[4] A. T. Henderson and K. L. Mapp, "A new wave of evidence: The impact of school, family, and community connections on student achievement," Southwest Educational Development, Austin, TX, 2002.

[5] UNESCO, Report on the expert meeting "Stopping violence at schools: what works? France: UNESCO, 2007.

[6] P. Batelaan, "Learning to respect," Intercult. Educ., vol. 12, no. 3, pp. 237-245, 2001.

[7] S. Polat and T. O. Barka, "Multiculturalism and Intercultural education: A comparative study with a sample of Swiss and Turkish candidate teachers," World Appl. Sci. J., vol. 18, no. 9, pp. 1180-1189, 2012.

[8] S. Fitriani, "Behavior contract and class routine for primary students: A case study in non-formal English institution," J. Inov. Pendidik. Dasar, vol. 4, no. 1, pp. 1-12, 2018.

[9] P. P. Hester, et al., "Lessons learned from research on early intervention: What teachers can do to prevent children's behavior problems," Prev. Sch. Fail. Altern. Educ. Child. Youth, vol. 49, no. 1, pp. 5-10, 2004.

[10] A. Frey and H. D. Doyle, "Classroom meetings: A program model," Child. Sch., vol. 23, no. 4, pp. 212-222, 2001.

[11] R. L. Curwin, Making good choices: Developing responsibility, respect, and self-discipline in grades 4-9. California: Corwin Press, INC., 2003.

[12] Kementerian Pemberdayaan Perempuan dan Perlindungan Anak Republik Indonesia, Panduan sekolah ramah anak. Jakarta: Deputi Tumbuh Kembang Anak, Kementerian Pemberdayaan Perempuan dan Perlindungan Anak Republik Indonesia, 2015.

[13] UNICEF, Child friendly schools programming: Global evaluation report. New York: UNICEF, 2009.

[14] B. Pont, et al., Improving school leadership. Volume 1: Policy and practice. Paris: OECD, 2008.

[15] OECD, "School boards- school councils: Pointers for policy development," 2008.

[16] L. Uiterwijk-Luijk, et al., "Promoting inquiry-based working: Exploring the interplay between school boards, school leaders and teachers," Educ. Manag. Adm. Leadersh., vol. 47, no. 3, pp. 475-497, 2019.

[17] M. L. Rehberg, "School committee of the town of Burlington v. Department of Education," Encyclopedia of Education Law. SAGE Publications, Inc, 2008.

[18] J. L. Epstein and F. L. Van Voorhis, "School Counselors' Roles in Developing Partnerships with Families and Communities for Student Success," Prof. Sch. Couns., vol. 14, no. 1, p. 2156759X1001400, 2010. 
[19] J. Bryan and L. Henry, "A model for building school-family-community partnerships: Principles and process.," $J$. Couns. Dev., vol. 90, no. 4, pp. 408-420, 2012.

[20] E. Hooge and M. Honingh, "Are School Boards aware of the educational quality of their schools?" Educ. Manag. Adm. Leadersh., vol. 42, no. 3, pp. 139-154, 2014.

[21] E. P. French, G. L. Peevely, and R. E. Stanley, "Measuring perceived school board effectiveness in Tennessee: The latest survey results," Int. J. Public Adm., vol. 31, no. 2, pp. 211-243, 2008.

[22] D. Land, "Local school boards under review: Their role and effectiveness in relation to students' academic achievement," Rev. Educ. Res., vol. 72, no. 2, pp. 229-278, 2002.

[23] A. Saatcioglu, S. Moore, G. Sargut, and A. Bajaj, "The role of school board social capital in district governance: Effects on financial and academic outcomes," Leadersh. Policy Sch., vol. 10, no. 1, pp. 1-42, 2011.

[24] M. Kriswantono and M. Muhyadi, "Implementation of the role of the school committee at SD Negeri Sumberporong 03, Lawang sub-district, Malang district (in Bahasa)," J. Akuntabilitas Manaj. Pendidik., vol. 1, no. 1 , pp. 66-79, 2013.

[25] A. Mustadi, E. Zubaidah, and S. Sumardi, "The role of the school committee in improving the quality of learning in elementary schools (in Bahasa)," Cakrawala Pendidik., vol. 3, no. 27, pp. 312-321, 2016.

[26] S. M. Christenson and Sandra L. Sheridan, Schools and families: Creating essential connections for learning. New York: Guilford Press, 2001.

[27] A. Petridou and Y. Karagiorgi, "Parental involvement and risk for school failure," J. Educ. Students Placed Risk, vol. 23, no. 4, pp. 359-380, 2018.

[28] X. Fan and M. Chen, "Parental involvement and students' academic achievement: A meta-analysis," Educ. Psychol. Rev., vol. 13, no. 1, pp. 1-22, 2001.

[29] J. Fantuzzo, C. McWayne, M. A. Perry, and S. Childs, "Multiple dimensions of family involvement and their relations to behavioural and learning competencies for urban, low-income children," School Psych. Rev., vol. 33, no. 4, pp. 467-480, 2004.

[30] R. Deslandes and R. Bertrand, "Motivation of parent involvement in secondary-level schooling," J. Educ. Res., vol. 98, no. 3, pp. 164-175, 2005.

[31] C. M. Colarusso, Ronald P. O'Rourke, Special education for all teachers, 4th edition. Dubuque, IA: Kendall/Hunt Publishing Company, 2007.

[32] K. L. Freiberg, Annual editions: Educating exceptional children, 18th edition. Dubuque, IA: McGrawHill/Dushkin, 2006.

[33] S. D. Pomerantz, Eva M. Moorman, and Elizabeth A. Litwack, "The how, whom and why of parents' involvement in children's academic lives: More is not always better," Rev. Educ. Res., vol. 77, no. 3, pp. 373-410, 2007.

[34] D. Cross, et al., "Three-year results of the Friendly Schools whole-of-school intervention on children's bullying behaviour," Br. Educ. Res. J., vol. 37, no. 1, pp. 105-129, 2011.

[35] T. Pickeral, L. A. Evans, W. Hughes, and D. Hutchison, School climate guide for district policymakers and education leaders. New York, NY: Center for Social and Emotional Education, 2009.

[36] UNESCO, World programme for human rights education: Second phase, plan action. New York and Geneva: United Nations, 2012

[37] OECD, Completing the foundation for lifelong learning: An OECD survey of upper secondary schools. Paris: OECD, 2004.

[38] J. Cohen, "Social, emotional, ethical and academic education: Creating a climate for learning, participation in democracy and well-being," Harv. Educ. Rev., vol. 76, no. 2, pp. 201-237, 2006.

[39] D. Rapti, "School climate as an important component in school effectiveness," Acad. Int. Sci. J., vol. 8, no. 8, pp. 110-125, 2013.

[40] B. Gilham, Case study research method. London: New York: Paston PrePress Ltd, 2000.

[41] R. K. Yin, Case study research: design and methods, Third edit. California: SAGE Publications Ltd., 2003.

[42] M. D. Gall, J. P. Gall, and W. R. Borg, Educational research: An Introduction., Eighth Edi. Boston: Pearson/Allyn \& Bacon, 2007.

[43] C. G. Knight, "Human-environment relationship: Comparative case studies," International Encyclopedia of the Social \& Behavioral Sciences. pp. 7039-7045, 2001.

[44] E. Brantlinger, R. Jimenez, J. Klingner, V. Pugach, and Marleen Richardson, "Qualitative studies in special education," Except. Child., vol. 71, no. 2, pp. 195-207, 2005.

[45] S. L. Yuniarti, L. Hayati, M. R. Zakaria, N. E. Prasetyo, and Nurmiyati, Technical guide: Special school partnerships with families and communities (in Bahasa). Jakarta: Direktorat Pembinaan Pendidikan Keluarga. Direktorat Jenderal PAUD dan Dikmas, Kementerian Pendidikan dan Kebudayaan, 2016.

[46] J. Devine and J. Cohen, Making your school safe: Strategies to protect children and promote learning. New York, NY: Teachers College Press., 2007.

[47] C. Lleras, "Hostile school climates: explaining differential risk of student exposure to disruptive learning environments in high school," J. Sch. Violence, vol. 7, no. 3, pp. 105-135, 2008.

[48] M. G. Sanders, Building school-community partnerships: Collaborating for student success. Thousand Oaks, CA: Corwin Press, 2005.

[49] W. Song, X. Qian, and B. Goodnight, "Examining the roles of parents and community involvement and prevention programs in reducing school violence," J. Sch. Violence, vol. 18, no. 3, pp. 403-420, 2019.

[50] E. Lesneskie and S. Block, "School violence: The role of parental and community involvement," J. Sch. Violence, vol. 16, no. 4, pp. 426-444, 2017. 
[51] C. R. Semiawan, Small notes on scientific research and development of knowledge (in Bahasa). Jakarta: Kencana, 2007.

[52] D. B. Davalos, E. L. Chavez, and R. J. Guardiola, "Effects of Perceived Parental School Support and Family Communication on Delinquent Behaviors in Latinos and White Non-Latinos," Cult. Divers. Ethn. Minor. Psychol., vol. 11 , no. 1 , pp. $57-68,2005$.

[53] J. Rudduck and J. Flutter, How to improve your school. London: Continuum, 2004.

[54] A. Becker, A. De Wet, and W. Van Vollenhoven, "Human rights literacy: Moving towards rights-based education and transformative action through understandings of dignity, equality and freedom," South African J. Educ., vol. 35, no. 2, pp. 1-12, 2015.

[55] L. Slater, "Relationship-driven teaching cultivates collaboration and inclusion," Kappa Delta Pi Rec., vol. 40, no. 2, pp. 58-59, 2004

[56] L. M. Pachter, P. Auinger, R. Palmer, and M. Weitzman, "Do parenting and the home environment, maternal depression, neighborhood, and chronic poverty affect child behavioral problems differently in different racialethnic groups?," Pediatrics, vol. 117, no. 4, pp. 1329-1338, 2006.

[57] E. Dearing, K. McCartney, and B. A. Taylor, "Within-child associations between family income and externalizing and internalizing problems," Dev. Psychol., vol. 42, no. 2, pp. 237-252, 2006.

[58] T. De Jong, "A framework of principles and best practice for managing student behaviour in the Australian education context," Sch. Psychol. Int., vol. 26, no. 3, pp. 353-370, 2005. 